\title{
Teachers' Experience in the Subject of Food and Health and the Promotion of Health in Norwegian Lower Secondary Schools
}

\author{
Else Marie Øvrebø \\ Faculty of Humanities, Social Sciences and Education \\ The Arctic University of Norway
}

\begin{abstract}
This study describes the teachers' experiences and views regarding the extent to which the subject food and health promotes health in lower secondary schools. The teachers wish to build their teaching on the pupils' assumptions and references, but they find this problematical because they have little or no knowledge of their pupils. In addition to support from the homes, the teachers point to sufficient economic resources in the schools, as well as resources in the shape of time and collegial support, as important factors in the realization of the subject. Although the teachers feel that they have the support they need in their work, very few have the organizational structures to lean on in their work, so that cooperation is barely internalized. Health-promoting work should be anchored throughout the organization, to achieve sufficient strength and effectiveness. Structural relationships within the organization, through organization management, are important for the teachers' work with the subject.
\end{abstract}

Keywords: Health-promoting work, Food and Health, teaching, implementation.

\section{Introduction}

There is no broader curriculum in Food and Health in Norway. The great majority of adolescents can effective be reached through school, which is an appropriate arena for health promotion (Kriemler, Meyer, Martin, Van Sluijs, Andersen, 2011; Anttila, Rytkönen,, Kankaanpää,, Tolvanen, \& Lahti, 2015). Food and Health is taught as a separate school subject in the sixth and ninth grades, for three hours per week. The aims of the training in the sixth grades are to enable the apprentice to:

- prepare safe and nutritionally sound food, and explain the place the different food groups have in the diet;

- explain how food acts as an energy source and building material for the body; 
- talk about the recommendations for a healthy diet from the health authorities, and give examples of the connection between diet, health and lifestyle.

In lower secondary school, the Food and Health course gives adolescents the opportunity to learn about food and living habits, something very important in promoting public health. Food and Health classes in school are the only form of instruction on food and living habits that many children receive. Living habits are also formed by the family, community and society (Gebremariam et al., 2012).

The schools' role in health promotion was also underlined in White Paper No. 30 (2003-2004) Culture for learning, (The Norwegian Ministry of Education, 2003), which was followed in 2006 by the Knowledge promotion reform.

As part of this reform, the subject of "Home Economics", which had been compulsory for all pupils since 1958, was changed to "Food and Health" and the subject curriculum altered to include a more health-related focus under the theme of "Food and Lifestyle".

"The purpose of the subject is to give children and young people fundamental practical skills and theoretical knowledge about food, food preparation, meals and diet. The purpose of the subject is to enable pupils to think about the personal choices they make in regard to food and lifestyle. Furthermore, pupils shall learn how to compose a nutritionally sound and good diet in line with the health authorities' recommendations" (Norwegian Government Ministries. (2007, pp 24).

The school is well suited for health promotion, but, to achieve sufficient strength and impact, the work must be rooted throughout the organization (Weare, 2002; Green \&Tones, 2010).

Only one in three of those who teach Food and Health in Norway $(30 \%)$ has a major in the subject (Lagerstrøm, Moafi, \& Revold, 2014). The professional qualifications of teachers who teach Food and Health have a bearing on the pupils' educational outcomes in the subject (Olufsen, Karlsen, \& Ødegaard, 2017). The competence of Food and Health teachers, to both stimulate adolescents' interest in Food and Health and provide the required knowledge and skills, is also an important factor (Hauge \& Mittelmark, 2003). Studies have shown, however, that the Food and Health teacher remains the primary source of nutrition information (Øverby et al, 2011; Øvrebø, 2014).

When Food and Health educators encounter the local curriculum, they must consider several didactic factors, such as goals and content, pupils' abilities, framework factors, learning activities and assessment (Arneberg \& Briseid, 2008; Hovdenak, 2009).

"All competency aims in the curriculum should be reviewed when Food and Health teaching concludes at the end of class 10, but it is up to each teacher to decide how much time it takes to achieve each individual competency (Scriven \& Hodgins, 2012). How extensively aims are 
treated, depends on the teachers` ideology on teaching" (Øvrebø, 2015, pp 73).

The challenge for the teacher is to choose learning materials, work methods and forms of feedback that increase the motivation of the pupils to choose a healthpromoting lifestyle (Øverby et al., 2011).

Food and Health is viewed as less important, with a lower status, than several other school subjects in Norway (Espeland et al., 2013). This is reflected in the local curriculum work and poorly organized and designed teaching kitchens. Food and Health is the smallest school subject, with the lowest number of hours allotted to it in Norway, but it is very important when it comes to giving pupils practical skills for daily life (Blegen, 2011; Joa, 2011). Other studies have also revealed that there is a need for teaching hours in Food and Health to be increased (Larsen, 2012; Øvrebø, 2014). "Food and Health in Norway is a practical subject that has traditionally driven training in line with the sociocultural learning, where learning through experience is central" (Øvrebø, 2015, pp.73).

When pupils participate in democratic learning processes in relation to the subject of Food and Health, they will be able to develop a democratic spirit and better understand the importance of being active and engaged participants in a community that has health challenges in the diet area.

Work on social skills regarding food and meals as described in the curriculum, aim at pupils development as independent individuals, who can assess the consequences of their eating behavior and take responsibility for that behavior. Pupils' cultural competence to participate in a multicultural society can be developed through their exposure to various cuisines.

In particular, training to help promote pupils' health can take place through targeted nutrition activities in Food and Health. Pupils use learning strategies in the organization of their own learning. In the diet work, opportunities will be given to learn strategies to plan, implement and evaluate the work of diet, reflect on new knowledge and apply it in new situations (Wilhelmsen \& Samdal, 2009). A learning strategy in working with diet may promote the motivation for learning and enhance the ability to solve similar tasks outside school. By allowing pupil participation in decisions concerning their own and group learning, the school can facilitate pupil participation in activities concerning Food and Health (Klepp \& Aarø, 2009).

Pupil participation in planning, implementing and evaluating the work of the curriculum in the Food and Health course assumes that pupils know the options and the consequences of their choices (Berg, 2007). Pupil participation allows for education that gives them an opportunity to participate in meals together, experience the joy of mastering work with food and reach their own goals for learning. In professional work with Food and Health, training is adapted to 
include variation in the use of teaching materials, working methods and teaching aids. There is also variation in the structure and intensity of training. Customized training is something that all pupils are entitled to, which implies that the teacher must facilitate the achievement of their potential professionally, socially and culturally - for all pupils (Holthe, 2009).

There is a little research on the subject Food and Health in Norway. Studies show that fruit and vegetables are included as a supplement in the practical subject in Food and Health. They are there just as a tool to produce a food dish. The pupils are interested in fruit and vegetables, but the Food and Health education less meets pupils regard ( Øvrebø, 2014; Kristoffersen, 2016). Another study raises the question: "Could it be that health education in primary schools is invisible"? (Øvrebø, 2014, pp.8)

\section{Aim}

The purpose of this study is to describe the experience and views of teachers.

To what extent is it teachers' experience that the subject of Food and Health promotes health in Norwegian lower secondary schools?

\section{Materials and methods}

"A letter was sent to the principals of 70 secondary schools from all 19 counties in Norway, inviting them to participate in the survey. Of these 70 schools, 60 responded positively to the request, and in-depth interviews were carried out involving 64 Food and Health teachers at 60 of these schools" (Øvrebø, 2015, pp.74).

The schools must have a certain size, so there could be at least two teachers who taught in Food and Health.

Table 1. Sample Characteristics

\begin{tabular}{|c|c|c|}
\hline Variables & $N=64$ & $\%$ \\
\hline \multicolumn{3}{|c|}{ Area/Province } \\
\hline North Norway & 14 & 26.7 \\
\hline Middle of Norway & 16 & 26.7 \\
\hline South Norway & 17 & 23.3 \\
\hline West Norway & 17 & 23.3 \\
\hline \multicolumn{3}{|c|}{ Urban/rural } \\
\hline Urban & 30 & 53.3 \\
\hline Rural & 34 & 46.7 \\
\hline \multicolumn{3}{|c|}{ Gender } \\
\hline Women & 55 & 83.3 \\
\hline Men & 9 & 16.7 \\
\hline \multicolumn{3}{|c|}{ Years of teaching } \\
\hline 1-4 years & 9 & 20.0 \\
\hline 5-10 years & 16 & 26.6 \\
\hline
\end{tabular}




\begin{tabular}{|lcr|}
\hline $11-15$ years & 33 & 33.3 \\
\hline $16-20$ years & 4 & 13.3 \\
\hline 21 years and more & 2 & 6.6 \\
\hline & Education in Food and Health & \\
\hline $0-15$ credits & 32 & 50,0 \\
\hline 30 credits & 16 & 25,0 \\
\hline $31-60$ credits & 6 & 9,4 \\
\hline Over 60 credits & 0 & 0 \\
\hline No education & 10 & 15,6 \\
\hline
\end{tabular}

"The characteristics of the respondents $(n=64)$ are presented in Table 1. The responses came from all four Norwegian provinces, with responses from urban and rural areas equal in number (Table 1). Approximately half $(53.2 \%)$ of the respondents had been teaching for over 11 years, the other half for between one and 11 years (Table 1). In this study, two Food and Health teachers at two of the municipality were used in the pilot test. The aim of the test was to determine how the interview guide would work. After pilot testing the interview guide, the information was reviewed in consultation with the pilot informants. The interview guide was semi-structured, with the main questions being formulated. It was possible to change the order in which the questions were posed, and allowance was made for the spontaneous formulation of follow-up questions. The study was in accordance with the requirements of the Privacy Ombudsman for Research at the Norwegian Social Science Services" (Øvrebø, 2015, pp 75).

Table 2. Interview guide with the questions that informants answered. (Without Subsequent questions).

Planning for Food and Health hours.

Can you tell how you plan what to be made in Food and Health class?

What do you mean about the term "health " in Food and Health?

What do you think when I say a healthy diet in relation to Food and Health?

How being students taught in competency aims of Food and Lifestyle?

How do you practice in the Food and lifestyle school kitchen?

Do you spend long time on this competency aim in relation to the other aims?

What do you put in the term student involvement?

Home importance in the subject?

Do linguistic skills have an impact on acquiring knowledge and skills in food and health?

Structural and organic support?

The teacher's competence in food and health?

What is the food and health subject's strength in being a health promotion subject for all students?

Background for teaching in Home Economics.

Education

Number of years as a Home Economics teacher 
"The interviews were conducted in the winter of 2016. They took place during teachers' working day, and each of the interview lasted 30 minutes. All teachers were informed about the purpose of the study and that they could stop the interview at any point without giving a reason. Written informed consent and an agreement that quotes from the interviews could be used anonymously were obtained from all teachers. All interviews are included in the analysis. In the process of analyzing the interviews, a branded Apple iPod was used as a recording machine. Each interview was transcribed on the day it was made, to ensure a description of the context of implementation.

Respondents were also informed that they could speak freely and that follow-up questions would be asked if necessary. Follow-up questions were usually asked to keep the interview on track in terms of obtaining answers to research questions and issues. The experience "came-into-language" in an open and transformative dialogue between the interviewer and interviewee. The researcher made an effort not to affect the dialogue's outcome according to her own perceptions and experiences but to allow the response of the interviewee to emerge. The respondents were relaxed, inspired by the questions, and capable of talking about their teaching about health in Food and Health.

In the presentation of the results, key points from the analysis are pointed out. In the interests of anonymity, respondents are referred to as Teacher 1, Teacher 2 etc". (Øvrebø, 2015, pp.76).

\section{Data analysis}

"All 64 interviews were transcribed verbatim. The transcribed data were read through several times and a coding frame for the analysis was developed. The analysis was performed as a phenomenological process, with systematic text condensation inspired by Giorgi (1985) and Malterud (2003) and meaning condensation (Kvale 1996). The analysis followed four steps: a) Reading all the material to gain an overall impression, b) identifying units of meaning representing different experiences and coding these units, c) condensing and summarizing the contents of the coded groups, and d) generalizing descriptions and concepts. Quotes from the interviews were translated from Norwegian to English by the author in the process of writing this article"(Øvrebø, 2015, pp.76).

\section{Results}

The following will be addressed in this section: Local curriculum, choice of teaching methods, linguistic awareness, pupils' experience, competence of teachers, academic emphases (collegial support, structural and organizational support). 


\section{Local curriculum}

For each theme in the local plan, the teacher is based on key concepts in the competence objectives and the related learning objectives. This gives pupils the opportunity to form a common understanding of the academic content and the correct use of concepts.

All competence goals are emphasized in the turn plan, and the basics of order and hygiene and yeast baking are repeated several times. Basic cooking methods are emphasized. (Teacher 1)

How the teachers at the individual school worked, according to the local curriculum in Food and Health, influenced how the teachers experienced working in the subject. For several teachers, this work had led to a negative experience, while others had found it a positive experience.

We use the local curriculum in the planning of the teaching. We emphasize the healthpromoting perspective in our annual plan. Food and Health is a practical subject, and the focus should be on the practical side. The theoretical aspect could also be "integrated into the practical". (Teacher 64)

We use the local curriculum in the planning of the teaching. I emphasize that pupils should make a conscious choice of which foods they eat. "Keyhole food" is a theme that the pupils are concerned with. I also place emphasis on traditional food. (Teacher 63)

Food bearing the keyhole logo is suitable for all healthy people - adults, teenagers and children. The keyhole is a voluntary Nordic food label. Compared to other foods of the same type, products bearing the keyhole logo comply with one or more of these requirements: more dietary fibre, less saturated fat, less salt, less sugar.

In the local curricum there are recommendations for a healthy diet that controls the food choice, such as the foods The Directorate of Health wants us to eat: more coarse grains, fish, vegetables and fruits. (Teacher 9)

Practical creative work, focusing on skills, testing and creativity, is central. Teachers have different experience with competency goals, but everyone emphasizes the basic methods in the subject, so that pupils are inspired for further work.

The goals in the local curriculum are ambitious. I emphasize that pupils will learn basic methods, be able to handle tools and incorporate good working habits. We make simple dishes like smoothies. The food should taste good. (Teacher 33)

Many teachers emphasize the health-promoting perspective in their annual plan. This is evident in the choice of dishes and foods and what is emphasized in the training. All teachers felt that the meal constitutes health promotion. The meal is an arena for the development of self-image, inclusion and mastery. 


\section{Choice of teaching methods}

All teachers use the so-called family method in organizing practical work. The family approach involves all pupils working in groups of three to four, in which all "family members" have their own tasks. This method is essentially based on two premises. Firstly, this means that all pupils get a better overview of all tasks; secondly, they are given the opportunity to support each other in their work tasks.

The goal is for as many pupils as possible gain an insight into as much as possible. If only someone who steaks meatballs then the others will not know anything about it. There will be no talk about it and no help either. (Teacher 44)

All teachers emphasize demonstration as an important methodological tool in practical work. This means that they show the pupils the practical tasks and explain them before the pupils themselves have a go.

We therefore place emphasis on showing in advance: displaying saucepans, tools and equipment they will use. Similarly, we display foods, while using the name of the food. We show how to use the knife correctly, for example by chopping fruit into a fruit salad. We need to work with terms that explain and make sense for the pupils. We try to give the concepts a content that the pupils can understand when we show them things. For example, what is the temperature of milk for yeast dough? They must "know" the right temperature so that, next time, they know how it will be. (Teacher 59)

Central to the subject is meeting new elements, that challenge the conceptual framework, and that pupils recognize and can use at the next meeting. In this subject, oral examinations are emphasized, by reviewing new teaching materials and by repetition of early-learning material. The pupils constantly meet new words and expressions that need to be taken into account by learning the concept first, then repeating it and performing the work; we call it bodyphenomenological understanding, "the knowledge of the hand" or the silent competence. : An example of this is the fact that the teacher can explain the use of a straight knife, while demonstrating it.

They have some practical homework, but it is also related to theory. It's not just practice. They must always know which nutrients are in the different ingredients. It's not only practical; we repeat it all the time. (Teacher 40 )

Many of the teachers brought up tasting as a theme they prioritize in the subject. Since this is a topic that is strongly emphasized, it also follows the methodology of the subject. Through exercise, pupils learn to put word on tasting, as well as changing their taste preferences. Many teachers felt that tasting is an important key to a healthy diet.

It's a little trick that, when we cook, everyone has to taste. Then they do not think that they are eating, but they have already tasted the food. They just think they are tasting whether there is enough salt or pepper. That's nice because they talk a little bit about taste too.

(Teacher 49) 
The subject is an arena that is accessible to all. Several of the teachers feel that, as Food and Health teachers, they have a particular responsibility to communicate the relationship between diet and health. They depict Food and Health as the most important venue for this dissemination of knowledge, and suggest that this is knowledge that can smooth the way for tackling social health issues.

The Health Directorate has its advice. We are the teachers, who have to convey the health advice. Then it becomes that those who are strong professionally will acquire that knowledge, while those who are not so academically strong and do not have that network will never be informed about the dietary advice. So, we have an important role in communicating. (Teacher 39)

Many of the teachers emphasize that the Food and Health subject's timetable sets limits on what they can do as teachers, and that they therefore prioritize presenting pupils with the values and the breadth of skills that they can take with them and practice outside school.

Creating a feeling of mastery among pupils seems to be a priority for teachers. Through their organization of Food and Health, they want it to be possible, even for pupils who are not so theoretically strong, to feel mastery.

I think that the Food and Health profession compensates for the other professional differences in school life. It gives everyone a chance to work well in another arena. Yes, feel mastery. Everyone reaches the goal of sitting around a table and enjoying themselves and has made something in common - the weak and the strong. (Teacher 19)

\section{Linguistic awareness}

According to the teachers, language is one of several barriers to the pupils' access to the subject of Food and Health. There is more talk, especially, about the challenges faced by foreign language pupils, but the teachers point out that language and awareness can be an obstacle to other pupil groups.

The language has a lot to say, meaning terms. Yes, I'm not just thinking about foreign languages. (Teacher 4)

Some teachers suggest that the lack of understanding of concepts in the subject may be related to pupils' experiences from home. If pupils are used to helping in the kitchen, this will be of importance in acquiring the education that is being delivered in the subject.

If it is common to talk about diet and health at home, then you understand words and concepts. You know what you're talking about when you get to school. Some pupils do not know how to knead a dough. (Teacher 48)

Food and Health is a practical subject with theoretical content. Many teachers say that there is a requirement for a relatively high level of language skills. They state that it is in relation to the theory content that the problems related to language and understanding of concepts are at their greatest. 
I feel that if they do not master reading, they are disadvantaged when it comes to reading recipes. (Teacher 57 )

All teachers emphasize that the subject is a resource in language learning. Through practical work, concepts are concretized. Many teachers mentioned the fact that classmates constitute a resource in Food and Health education. Although all the teachers point to languages and concepts as a challenge in the subject, they face the language barriers in different ways. Some work with conceptual learning in the subject in a conscious and structured way, while others believe that the time is either too short or this may also be a waste of time.

Pupils receive a sheet of recipes and procedures, which they place in a folder. I am careful to explain and show. Here, basic skills, with an emphasis on oral emphasis are placed on in a dialogue between me and pupils (Teacher 22).

\section{Pupils' experiences and background}

Several of the teachers point out that they have little knowledge about the pupils' home and the professional status of their families when they come to Food and Health education. Many teachers may prefer to have more background information, in order to better accommodate pupils.

This year I have asked to attend a meeting between school and home because I think it's okay to know a little about each pupil, about how they are in academic achievement, especially in terms of reading (Teacher 42 ).

All the teachers mention about pupils who want to share their experiences in Food and Health education. These may relate to past experiences, or pupils like to tell that they have tried out at home some of the dishes they have learned at school. More than half of the teachers want to build on the experiences that the pupils share. They recognize the pupils' frame of reference as far as possible. Lack of time is also described as a limitation in this context.

Pupils always share. For example, if we are going to bake rolls, there is always someone who says that they have done that before. It is very easy to tell that they have done that before. (Teacher 12)

Several of the teachers are concerned that pupils from other cultures should feel recognition of their background. Teachers are conscious of facilitating and displaying necessary considerations in connection with food, and some of them also describe how they want to use the different cultures as a teaching resource.

When I send letters in the autumn, I ask parents who come from other countries to come up with recipes that we can use. The goal is to be able to cook food from the countries from which the pupils originate. (Teacher 15)

The pupils' experience of sharing is primarily linked to the practical part of the subject. The knowledge and experience of the pupils does not cover the theoretical subjects in 
Food and Health. There are very many who do not know what the food does to the body. (Teacher 27)

If you want to make any of the dishes we make, then we use many reasonable and healthy ingredients. Everyone should be able to do it at home. (Teacher 3)

Although pupils are encouraged to practice their knowledge at home, not everyone does so. Some parents do not allow their children in the kitchen, and some pupils also do not have the necessary raw materials available to make healthy food. Conversely, many of the teachers express the positive importance the home can have for mastery in Food and Health.

Teachers say that home resources are the biggest challenge for Food and Health in terms of being a health-promotion subject.

The main challenge for Food and Health in relation to its being a health-promotion subject is the background of the pupils. (Teacher 5)

\section{Pupils' influence}

Most of the teachers are quite clear that the principle of pupil participation is present in their teaching, but it is part-time participation. Several teachers believe it is easier to facilitate pupil participation beyond the school year, when the pupils have gained more experience in the subject.

It is very interesting that, earlier this autumn, I decided who would do what, while now I give that responsibility to the pupils. (Teacher 16)

It's very expensive if somebody is going to choose what to make, but we have choices within certain limits. (Teacher 31)

After Christmas we will have a week or two where we have the pupils' choice, where they can decide the menu. (Teacher 17)

We're not so good at involving pupils. However, in connection with theory, they can come up with their opinions. They can determine the content of a lesson. Then they can plan and shop. Pupils should pick out the nutritionally good food. This is only once a year. (Teacher 21)

\section{Teachers' competence}

Many of the teachers have relevant college education in Food and Health. They emphasize that this is an important and necessary prerequisite for teaching the subject. A professional qualification makes you safer in the teaching role, while contributing to the quality assurance of the teaching being delivered.

You need to have a professional background. Because if one does not, it will be more of a cookie course. It is not important to know how to make white sauce without lumps. But in Food and Health, I think health should be central. (Teacher 55) 
Some teachers believe that personal competence is vital in the role of a teacher. They talk about the importance of dissemination and loving both people and the subject.

It's important that you love people. That you show that it's fun to be in the kitchen, which is infectious. It is important to show that all food is good. (Teacher 52)

Very few teachers can tell about academic refills in the form of courses and further education in Food and Health. One of the teachers says that the course gave her confirmation that her teaching represented values that were good. Many of the teachers feel that the subject of Food and Health has a slightly lower status, compared with that of other subjects.

\section{Collegial support}

The teachers had different experiences of cooperation with their colleagues. Good collaboration with colleagues can have a positive impact on the quality of teaching, while bad cooperation may have an adverse effect. Colleagues' expertise in the subject and the amount of time spent on cooperation affects the quality of the collaboration.

We will have some collegiate time for seminars and so on, then I may feel that the subject will be given priority and I have good collaboration with my colleagues. (Teacher 7)

No interest in collaborating because the other teachers did not have good enough skills in the subject. Nor was there time for cooperation. (Teacher 53)

Many teachers talk about little cooperation with other teachers in Food and Health. Much of the planning in the subject is done alone.

\section{Structural and organizational support}

For teaching to be successful and for one to thrive in the job as a Food and Health teacher, most teachers consider sufficient time for preparatory work and rework to be important.

I spend a lot of time on preparatory work and rework. Purchasing takes a lot of time. (Teacher 1)

Many of the teachers also point to time as a challenge in the realization of the subject.

The hours per-year in the subject are limited and for the learning outcomes to be optimal, the teaching must be organized in a period of time, which is appropriate for the learning activities that take place.

Sufficient financial resources for purchasing raw materials and equipment's are described by all teachers as crucial to the realization of Food and Health. Many teachers do not have sufficient funds to buy the raw materials they need, and many lack technological equipment's for use in their teaching. 
We do not have any laptops, PCs or projectors down at the kitchen. But then I'm not the headmaster, so I cannot decide. (Teacher 11)

Several of the teachers emphasize that the values and content of the subject have gained ground in the school organization. Some teachers are responsible for the choice of physical activity and health in grade 10.

\section{Discussion}

The teachers consider that they play an important role in health promotion among children and young people. This is due to both the form and content of the subject (Hauge \& Mittelmark, 2003). At school, one can reach all the youth in the community, regardless of their socioeconomic position (Gebremariam et al., 2012). Consequently, the school is a suitable learning arena for encouraging health-promoting habits among schoolchildren (Anttila et al., 2015; Kriemler et al., 2011; Parcel, Kelder \& Basen-Engquist, 2000).

Teachers emphasize the health-promotion perspective in their local curriculum. Teachers get ideological power to define the subject content and weighting within the national framework that is set (Hovdenak, 2009). This implies that teachers also have great freedom to include local and very different subjects in the education (Arneberg \& Briseid, 2008).

The education should be adapted to the pupils so that they can experience a sense of mastery and be motivated to use the knowledge in their daily lives. The subject has both a practical and a theoretical dimension. Many teachers try to merge theory and practice. This is in order for most pupils to experience a sense of mastery (Øvrebø, 2008). All teachers organize the practical work in smaller groups (family groups); doing so facilitates a focus on social relations, both between teacher and pupil and between the pupils. In the subject, Food and Health, the socio-cultural perspective of learning has been strong, with a focus on learning through experience. Within a socio-cultural learning theory perspective, the abstract and the concrete goes hand in hand, and do not live separate lives, as we often experience in formal education. Contentiously, collaborative ability and social competence will be important keywords, combined with a learning community, where the sum of the individual's contribution constitutes the wholeness (Hovdenak, 2009). The training has specifically focused on helping promote the health of pupils through targeted dietary activities.

Learning strategies in the diet work have been linked to the ability to plan, carry out and evaluate work with diet, reflect on new knowledge and apply it in new situations (Wilhelmsen \& Samdal, 2009). The teachers believe that it is important to teach basic practical skills, and they focus on making food that is not so resource-intensive. They do this because the pupils will take their knowledge and skills back home with them. Since Food and Health are allocated for few hours, they consider it important that the subject content and values are also strengthened at home. Parents have the most significant role in the influence of children and young people's health behavior (McKeown \&Nelson, 2018). A 
previous study shows that health promotion in school must be supported and strengthened through cooperation with the parents (Parcel et al., 2000). Through the development of practical skills, pupils are able to make health-promoting choices. Health-promotion measures based on skills have great importance (Hawkins \& Catalano, 1992).

Health-promotion education is more than just knowledge transfer (Weare, 2002; Green \&Tones, 2010). Learning must also involve the development of skills. Through the development of practical skills, pupils are able to make healthpromoting choices. Autonomy is not created through health-promoting education that suggests that factual information automatically means changing of health behavior. Several studies that have compared health promotion measures based on skills with actions focused on values and attitudes also show the importance of skills (Hawkins \& Catalano, 1992). For the pupils to be able to use their knowledge from the subject of Food and Health, it is important that the kitchen, equipment and working methods are updated and modernized. Resources, in the form of money for the purchase of digital equipment and raw materials, are also important (Østby, 2015).

Although Food and Health is a practical subject, teachers say that language is a barrier to many pupils. Teachers' lack of knowledge about pupils assumptions can reinforce these language barriers. For teachers, working with concepts was a prioritized part of their teaching. This study emphasized that the practical work in Food and Health can seem like a resource for conceptual learning, by providing good opportunities for concretization (Østby, 2015).

All subjects will win, through pupils' mastering of verbal language, both to clarify their own understanding of the subject and to develop the concepts of the subject (Øvrebø, 2008). This is especially the case in Food and Health, because "Low-level language skills in Food and Health can be an obstacle to healthy food and meal choices, while high-level language skills can help promote a healthy diet" (Wilhelmsen \& Samdal, 2009).

According to the theory of public reproduction, the knowledge of the pupils is world of experience and it must be seen in conjunction with the contextual conditions of the subjects (Hargreaves, 2004). This is how you can assess whether the contextual conditions are equally well suited to all pupils. When teachers present experience sharing more as spontaneous than planned activity enshrined in local learning plans, this may mean that the pupils experience is less systematically emphasized, such as working methods (Goodlad, 1979). Due to the small emphasis on contextual conditions in promoting health, the formal curriculum is not realized.

Weare (2002) underlines the importance of this view by claiming that pupils are not empty bottles to be filled up or blank sheets to be discarded. Pupils build new knowledge on existing knowledge in a continuous interaction with the outside world. Through better knowledge of the pupils' preconditions and experiences, lessons can increasingly be adapted to them. 
An important task for the teacher is, therefore, to find out how the subject can become part of the pupil's experience in order to be further developed. The teachers' desire for insight into their pupils' experiences is challenged by the subject's scarce time resource and lack of anchoring in local curricula. Knowing about pupils experiences is important for understanding the interaction between the contextual conditions in the school and the pupil's actions. Through such an understanding, school and education can be further developed, so that as many pupils as possible realize their potential for learning and development (Nordahl, 2010).

Although teachers are uncertain about how much pupils should participate in the planning and implementation of the teaching, they arrange for pupils to make more choices throughout the school year, which demonstrates a conscious actor's perspective on teaching (Holthe, 2009). The participation of the pupils leads to a sense of ownership and their taking more responsibility (Berg, 2007), with pupils receiving improved learning outcomes and increased control over their own health. At the same time, in the school, there is the teacher who has the greatest influence in relation to the pupil (Scriven \& Hodgins, 2012). Most teachers believe that pupils should have more say in the planning and implementation of the teaching. The teachers do not practice pupil participation in topics because the pupils do not have enough insights into the guidelines of the subject (Øvrebø, 2008).

Empowerment presupposes both attitude and behavioral changes among professionals who represent quite extensive value choices (Stang, 2003). For some teachers, this may require a reassessment of the teacher's role and increased reflection about traditional power relations. This study indicates that the teachers tend to strive for an attitude in which pupils must be guaranteed active participation and participation. Pugilism as full self-determination is not the goal. Empowering education is a critical-democratic pedagogy for self and social change. Empowerment does not mean pupils and the teacher can do whatever they like in the classroom. The learning process is negotiated, requiring leadership by the teacher and mutual teacher-pupil authority (Shor, 1992). The central factor for pupils is increased participation rights (Klepp \& Aarø, 2009).

Relevant education is necessary to ensure not only quality in teaching but also benefits and safety at work. Many teachers in Food and Health are not properly qualified and lack the necessary competance (Lagerstrøm et al., 2014; Øvrebø, 2015). School owners' priorities and emphasis on the above-mentioned framework factors can have an impact on the academic content of the education (Gustafsson, 2003). Teachers who are confident in didactics, both academically and professionally, manage to provide high-quality teaching (Olufsen et al., 2017), and the teacher's knowledge in the subject is important for giving pupils a high level of learning outcome (Momota \& Ogawa, 2018; Gustafsson, 2003). 
Colleague cooperation in the subject is not systematic and occurs largely on their own initiative. Health-promoting work should be anchored throughout the organization, to achieve sufficient strength and effectiveness (Weare, 2002). Structural relationships within the organization, through organization management, are important for the teachers' work with the subject. A common perception is that the subject's curriculum and objectives are too extensive in relation to the number of teaching hours, which are not sufficient to give the pupils the competence that the curriculum describes (Østby, 2015). Early studies have shown that teachers have pointed out that having to implement the changes alone is one of the main obstacles in their attempts to effect change (Hargreaves, 2001)

"During and after the interviews, there were factors that could affect the study's validity. Considerable preparatory work was carried out on the questions in the interview guide in advance, while follow-up questions were devised as the interview progressed. The follow-up questions were asked to keep the interview on the right track in response to the research questions and the aim. The follow-up questions could have influenced the informants' statements, to a greater extent than those in the interview guide, as they were posed more spontaneously. The researcher`s understanding will not only affect the interview situation but also the other parts of the project, from the selection of the problem to the finished result.. After all the interviews were completed, the researcher had extensive material to process and analyze, which could possibly have made the analysis less clear and thus weakened the reliability. In the analysis phase, it may be an advantage for more people to be involved in the work" (Øvrebø, 2015, pp. 82).

\section{Conclusion}

Several of the teachers, as Food and Health teachers, feel that they have a particular responsibility to communicate the relationship between diet and health. Teachers emphasize the health-promotion perspective in their local curriculum. Many of the teachers emphasize that the Food and Health subject's timetable sets limits on what they can do as teachers. All the teachers point to languages and concepts as a challenge in the subject. The teachers point out that they have little knowledge about the pupils' home and the professional status of their families when they come to Food and Health education. The teachers wish to build their teaching on the pupil's assumptions and references, but they find this problematical.

All the interviewees in the study, point to sufficient economical resources in the schools, and resources in the shape of time and collegial support, as important factors in the realization of the subject. Although the teachers feel that they have the support they need in their work, very few have the organizational structures to rely on in their work, so that cooperation is barely internalized. 
Teaching hours in Food and Health must be increased. Many Food and Health teachers are not properly qualified and lack the necessary competence. Relevant education necessary to ensure not only quality in teaching but also benefits and safety at work. The education in Food and Health in the university must be more health promotion.

\section{Acknowledgments}

The authors are grateful to the study participants for sharing their thoughts and experience.

\section{References}

Anttila, J., Rytkönen, T., Kankaanpää, R., Tolvanen, M., \& Lahti, S. (2015). Effect of national recommendation on sweet selling as an intervention for a healthier school environment. Scandinavian Journal of Public Health, 43(1), 27-34. doi.org/10.1177/1403494814558150

Arneberg, P. \& Briseid, L. G. (2008). Fag og danning : mellom individ og fellesskap. [Subject and formation: between individual and community]. Bergen: Fagbokforlaget.

Berg, N. B. J. (2007). Elev og menneske-Psykisk helse i skolen. [Pupil and Human-Mental Health in School].Oslo: Gyldendal Akademisk.

Blegen, H.H. (2011). Nutrition literacy hos 10. klasse elever i en Østlandskommune.[Nutrition literacy in 10th grade in an eastern municipality].[Master in Food, Nutrition and Health]. University of Oslo and Akershus.

Espeland, M., Arnesen, T. E., Grønsdal, I. A., Holthe, A., Sømoe, K., Wergedahl, H., \& Aadland, H. (2013). Skolefagsundersøkelsen 2011. Praktiske og estetiske fag påbarnesteget $i$ norsk grunnskule. [The school subject survey 2011. Practical and aesthetic subjects at the children's stage in the Norwegian primary school]. Stord: HSHrapport 2013/7.

Giorgi, A. (1985). Sketch of a psychological phenomenological method. In: A. Giorgi (ed.), Phenomenology and Psychological Research. Pittsburgh, Pa: Duquesne University Press, (pp. 8-22). Pittsburgh, PA: Duquesne University Press. Giorgi, A.A: Duquesne University Press. Giorgi, A.

Gebremariam, M. K., Totland, T. H., Andersen, L. F., Bergh, I. H., Bjelland, M., Grydeland, M., Ommundsen, Y. \& Lien, N. (2012). Stability and change in screen-based sedentary behaviours and associated factors among Norwegian children in the transition between childhood and adolescence. BMC Public Health, 12(1), 104-112. doi: 10.1186/1471-2458-12-104

Goodlad, J.I. (1979). Curriculum Inquiry: The Study of Curriculum Practice. New York: McGraw-Hill Book Company.

Green, J., \& Tones, K. (2010). Health promotion: Planning and strategies, (2nd ed. London, Sage.

Gustafsson, J. E. (2003). What do we know about effects of school resources on educational results? Swedish Economic Policy Review, 10(2), 77-110.

Hargreaves, A. (2001). The emotional geographies of teachers' relations with colleagues. International Journal of Educational Research, 35(5), 503-527. doi:10.1016/S08830355(02)00006-X

Hargreaves, A. (2004). Læring og undervisning $i$ kunnskapssamfunnet. Utdanningi en uttrygg tid. [Learning and teaching in the knowledge society. Education in an uncertain time.] Oslo: Abstrakt forlag. 
Hauge, H. A. \& Mittelmark, M. B (2003). Helsefremmende arbeid i en brytningstid. Fra monolog til dialog? [Health-promoting work at a break time. From monologue to dialogue?] Bergen: Fagbokforlaget.

Hawkins, J., \& Catalano, R. (1992). Communities That Care: Action for Drug Abuse Prevention. San Francisco: Jossey-Bass.

Holthe, A. (2009). Fra sentralgitt plan til lokale planer i mat og helse. [From the central plan to local food and health plans]. In: A. Holthe \& B.U. Wilhelmsen (eds.), Mat og helse i skolen - en fagdidaktisk innforing, 1st edn. [Food and health in school - a subject didactic introduction,] (1 ${ }^{\text {st }}$ ed). Bergen: Fagbokforlaget, pp. 23-25.

Hovdenak, S. S. (2009). Kostholdsinformasjon og annen helseinformasjon. [Diet information and other health information]. In: A. Holthe \& B.U.Wilhelmsen, (eds.), Mat og helse i skolen-en fagdidaktisk innføring,. [Food and health in school - a subject didactic introduction,] (1 ${ }^{\text {nd }}$ ed). Bergen: Fagbokforlaget, pp. 233-244.

Joa, B. K. (2011). A sustainable school kitchen? A study of Food and Health teachers in secondary schools' teaching strategies about the theme "Project: Be Truly Sustainable". [Master in Food, Nutrition and Health]. University of Oslo and Akershus.

Klepp, K-I. \& Aarø, L. E. (red.) (2009): Ungdom, livsstil og helsefremmende arbeid. [Youth, lifestyle and health promotion]. Oslo: Gyldendal Norsk Forlag.

Kriemler, S., Meyer, U., Martin, E., Van Sluijs, E. M. F., Andersen, L. B., \& Martin, B. W. (2011). Effect of school-based interventions on physical activity and fitness in children and 87.adolescents: a review of reviews and systematic update. British Journal of Sports Medicine, 45(11), 923-930. doi: 10.1136/bjsports-2011-090186

Kristoffersen, M. (2016). Fruit and vegetables in food and health. A Case study. [Master in Food, Nutrition and Health]. University of Bergen.

Kvale, S. (1996). Interviews: An Introduction to Qualitative Research Interviewing. Thousand Oaks, CA: Sage.

Lagerstrøm, B. O., Moafi, H., \& Revold, M. K. (2014). Kompetanseprofil i grunnskolen. Hovedresultater 2013/2014 Rapporter. Oslo: Statistisk sentralbyrå.

Larsen, B.S. (2012). Kosthold som helsefremmende faktor for ungdom. En studie av ungdommers erfaring og kunnskap etter opplæring i faget Mat og helse, sett i lys av ny folkehelselov. [Diet as a health promoting factor for youth. A study of young people's experience and knowledge after training in the subject Food and health, in light of new public health law]. [Master in Food, Nutrition and Health]. University of Gjøvik.

Malterud, K. (2003). Kvalitative Metoder i Medisinsk Forskning: En Innføring. 2.utg. [Qualitative Methods in Medical Research: An Introduction. 2nd ed.; in Norwegian]. Oslo: Universitetsforlaget.

McKeown, A., \&Nelson, R. (2018). Independent decision making of adolescents regarding food choice. International Journal of Consumer Studies, 42:469-477 .doi.org/10.1111/ijcs.12446.

Momota, Y., \& Ogawa, I. (2018). Education of Craft with Fabrics in Home Economics for Elementary School Students. International Journal of Learning, Teaching and Educational Research, 17(3), 15-27. doi.org/10.26803/ijlter.17.3.2

Nordahl, T. (2010): Eleven som aktør. Fokus på elevens læring og handlinger i skolen. [The student as an actor. Focus on the student's learning and actions in school.] Oslo: Universitetsforlaget.

Norwegian Government Ministries. (2007). Handlingsplan for bedre kosthold i befolkningen (2007-2011) Oppskrift for et sunnere kosthold (Plan of action for nutrition (2007-2011) recipe for a healthier diet). Oslo: Norway. 
Olufsen, Magne; Karlsen, Solveig \& Ødegaard, Marianne (2017). Endringer i lærerstudenters kompetanser? En casestudie fra en ny lærerutdanning ved UiT Norges arktiske universitet. [Changes in teachers' competences? A case study from a new teacher education at UiT Norway's Arctic University.] Nordina: Nordic studies in science education. 13(2), 117- 133. doi.org/10.5617/nordina.3140

Parcel, G.S., Kelder, S.H., \& Basen-Engquist, K. (2000). The School as a Setting for Health Promotion. In B.D. Poland, L.W. Green, \& I. Rootman (eds.), Settings for Health Promotion. Linking Theory and Practice (pp.86-120). Sage: London. doi.org/10.4135/9781452232829.n3

Pettersen, R. C. (2007). Students' experience and evaluation of teachingand learning environment: presentation of the Course Experience Questionnaire (CEQ) - and validation of three Norwegian versions (EMS). University of Østfold.

Rappaport, J. (1987) Terms of empowerment/exemplars of prevention: toward a theory for community psychology. Am J Community Psychol 15(2), 121-148. doi.org/10.4135/9781446288962

Stang, I. (2003) Bemyndigelse : en innføring i begrepet og "empowermenttenkningens" relevans for ansatte $i$ velferdsstaten. I: Helsefremmende arbeid $i$ en brytningstid : fra monolog til dialog? [ Authorization: an introduction to the concept and the "empowerment thinking" relevance for employees in the welfare state. In: Health promotion in a break time: from monologue to dialogue?], red.: Hauge, H. A. \& Mittelmark, M. B., s. 141161. Bergen: Fagbokforlaget.

The Norwegian Ministry of Education. (2003). White Paper no. 30 (2003-2004): Culture for learning (in Norwegian). Oslo.

The Norwegian Ministry of Education and Research. (2008). (2007-2008). Oslo.

Wayne, A. J., \& Youngs, P. (2003). Teacher characteristics and pupil achievement gains. Review of Educational Research, 73(1), 89-122. doi.org/10.3102/00346543073001089

Weare, K. (2002). The contribution of education to health promotion. In: R. Bunton \& G. Macdonald (eds.), Health Promotion. Disciplines, Diversity and Developments, 2nd edn. London: Routledge, pp. 102-125.

Wilhelmsen, B. U., \& Samdal, O. (2009). Kostholdsinformasjon og annen helseinformasjon. [Diet information and other health information]. In: A. Holthe \& B.U. Wilhelmsen, (eds.), Mat og helse i skolen. [Food and health in school]. Bergen: Fagbokforlaget.

Østby, M. (2015) Mat og helse som et helsefremmende fag $i$ skolen: En kvalitativ studie om hvordan det tilrettelegges for mat og helse-fagets rolle inn i nasjonalt helsefremmende arbeid. [Food and health as a health-promoting subject in the school: A qualitative study on how it facilitates the role of food and health in national health promotion work]. Master thesis. University of Vestfold and Buskerud.

Øverby, N., Klungland Torstveit, M., \& Høigaard, R. (2011). Hva er folkehelse og folkehelsearbeid? [What is public health and public healthwork?] Mat og helse $i$ skolen [Food and health in school] 3(2), 4-6.

Øvrebø, E. M. (2008). Fagdidaktikk i mat og helse. [Didactics in Food and Health; in Norwegian]. Kristiansand: Høyskoleforlaget.

Øvrebø, E. M. (2014). Knowledge and attitudes of adolescents regarding home economics in Tromsø, Norway. International Journal of Consumer Studies, 38(1), 211. doi.org/10.1111/ijcs.12043

$\varnothing v r e b ø$, E. M. (2015). How Home Economics Teachers in Norwegian Lower Secondary Schools Implement sustainability in their Teaching? International Journal of Learning, Teaching and Educational Research, 10(2), 72-83. 